\title{
KOŚCIÓŁ KATOLICKI W POLSCE W PRZESTRZENI ŻYCIA PUBLICZNEGO - ANALIZA SOCJOLOGICZNA
}

\section{ABSTRACT The Catholic Church in Poland in the area of public life: A sociological} analysis

For the last few years, a slow process of a specific "cooling down" of religious and Church commitment has been taking place in Poland. In this article we assume that religiosity with institutional protection still plays an important role in the Church landscape of Polish society and the sphere of public life. In Poland, a positive attitude vis-à-vis the Catholic Church is an important determinant of one's religiosity. Individuals who do not have confidence in the Church, and who evaluate it negatively as an institution, tend to participate less in religious practices, and their faith seems to be weakening. Religiosity and commitment to the Catholic Church in Poland are very closely related to each other. There are no major discrepancies in the opinion as to the extent of the secularization of society among Polish sociologists, but there are differences in the assessment and understanding in terms of the social role of the Church. Discussions on the position and role of the Catholic Church in society still go on, and we are far from a conclusive diagnosis, especially regarding our understanding and acceptance of a "model Church" that should function in a democratic and pluralistic society. The final answers remain in the realm of hypotheses and assumptions.

The majority of Poles are convinced about the Church's influence in various spheres of public life, including the political sphere. This view is predominant among almost two thirds of adult Poles, but also among the youth (even to a somewhat greater extent). This means that the Church is perceived by part of Polish society as a quasi-political institution, or at least one that attempts to fulfill political functions. This view, which is quite popular among Poles, has been 
maintained at a relatively stable level since 1989. Among those who believe that the Church takes up too much space in the public life of Poland are found those people in whom every reference to public matters results in a rejection reaction, as well as among those who take on a moderate attitude, who consider that it would be better if the Church were less involved in matters of public life, particularly political. Most Poles accepts the principle of separation of Church and state, even though close to half of those surveyed have nothing against authorities who follow the Catholic social teaching. The views of many Poles on the place and role of the Church in the public life of the nation are to a certain extent ambivalent, and even inconsistent and incoherent. A major subject of public controversy is the presence of religious symbols in public life space, although most of Polish society speaks about such symbols with approval.

Keywords: Catholic Church, public life, the Church and politics, religious symbols

Słowa kluczowe: Kościół katolicki, życie publiczne, Kościół a polityka, symbole religijne

7 perspektywy socjologicznej Kościół może być przedmiotem badań jako instytucja historyczna i społeczno-kulturowa, zmienna zarówno co do formy, jak i funkcji. Współcześnie zinstytucjonalizowane wymiary Kościołów, zwłaszcza rzymskokatolickiego, podlegają procesom dezinstytucjonalizacji i pluralizacji społecznej. Dla socjologa Kościól jest organizacją społeczną jednoczącą tych, którzy mają wspólne przekonania religijne, podejmują wspólne działania, uznają podobne wartości, akceptują pewne struktury hierarchiczno-organizacyjne itp. Socjologia ujmuje Kościół z perspektywy zmian jego pozycji i roli w społeczeństwie, nie zajmuje się zaś prawdziwością wiary religijnej, rozważa społeczne aspekty wiary i Kościoła, ich zmiany w warunkach transformacji ustrojowej. Socjologowie próbują zrozumieć i objaśnić dokonujące się zmiany w religijności i kościelności w ich społecznych wymiarach.

W Polsce przejście od państwowego socjalizmu do demokratycznego państwa prawa i związana z tym gwałtowna zmiana świadomości ludzi sprawiają, że Kościół znajduje się w fazie eksperymentu wychodzenia z epoki ukształtowanej mniej lub bardziej przez religię katolicką i przejścia do nowej sytuacji nacechowanej pluralizmem społeczno-religijnym. Ta nowa faza charakteryzuje się przede wszystkim przemianą wartości religijno-kościelnych, „wymuszoną” przez zmieniające się sytuacje społeczne. W okresie przejściowym może dochodzić do konfliktów pomiędzy społeczeństwem pluralistycznym a Kościołem katolickim. Podobnie jak w okresie dyktatury ateistycznej, tak i dzisiaj nauczanie i działalność Kościoła w życiu społecznym budzą sprzeciw w pewnych środowiskach opiniotwórczych. Troska Kościoła o podbudowę moralną politycznych, ekonomicznych i społecznych procesów transformacyjnych 
nie zawsze jest oceniana pozytywnie. Wyraża się wątpliwość, czy tradycyjny Kościół katolicki w Polsce jest zdolny wnieść pozytywny wkład w rozwój i stabilizację społeczeństwa demokratycznego i obywatelskiego, a nawet czy w ogóle powinien działać w przestrzeni życia publicznego. Niekiedy dostrzega się w nim zagrożenie dla wolności i demokracji.

W modernizującym się w latach 90. XX wieku społeczeństwie polskim Kościół angażujący się w problemy społeczne i polityczne naszego kraju był oceniany w rozmaity sposób, zarówno z aprobatą, jak i dezaprobatą. Wielu, zwłaszcza młodych, ludzi sądzi, że Kościół nie daje zadowalających odpowiedzi na problemy społeczne dotyczące jednostki, rodziny, warstw społecznych i narodu. Upowszechniona w społeczeństwie polskim pozytywna ocena społecznej i religijnej działalności Kościoła zaczyna się nieco pogarszać z chwilą przechodzenia z ogólnej płaszczyzny jego działalności na płaszczyznę spraw bardziej konkretnych, związanych z życiem codziennym. Nie oznacza to, że Kościół utracił żywotność i ważność dla życia społecznego, dla budowania konsensu i urabiania zbiorowej świadomości. Pozostaje on integralną częścią dziedzictwa kulturowego narodu, ważnym składnikiem jego tożsamości i źródłem wielu szlachetnych wartości społecznych oraz ważnym partnerem na polskiej scenie publicznej. Ocena konkretnej działalności Kościoła ujmowana w kontekście osiąganych rezultatów jest już bardziej zróżnicowana i wyraźnie umiarkowana. Wydaje się nawet, że przybywa głosów krytycznych.

W warunkach społeczeństw pluralistycznych i ponowoczesnych tolerowane są w sprawach religijnych różnorodne postawy, także i manifestowany brak przekonań religijnych. Dokonuje się ustawiczna transformacja i restrukturyzacja religii, która nie musi zawsze oznaczać triumfu sekularyzacji. Dowody osłabienia wiary i praktyk religijnych w jednych dziedzinach życia społecznego są równoważone przez świadectwa odradzania się żywotności i dynamiki religijnej w innych. Różne obszary życia społecznego nie są od siebie odizolowane, zmiany w jednych pociągają za sobą przekształcenia $\mathrm{w}$ innych. Religijność podlega zmianom uwarunkowanym także szerszym kontekstem społecznym, nawet jeżeli modyfikacje w tym obszarze nie następują zbyt gwałtownie ${ }^{1}$. Ten szerszy kontekst w odniesieniu do społeczeństwa polskiego stanowi wielość czynników politycznych, społecznych i gospodarczych, działających równolegle i wzajemnie ze sobą powiązanych. Nazywa się je niekiedy zmianą systemową, wielką przemianą, transformacją ustrojową, modernizacją społeczną.

W ostatniej dekadzie XX wieku Polska weszła w orbitę bardziej intensywnych wpływów płynących z Europy Zachodniej. W związku z tym procesy sekularyzacyjne typowe dla tego kontynentu mogą oddziaływać w sposób bardziej wyraźny na polskie społeczeństwo. Wielu socjologów, zwłaszcza zachodnich, prognozuje przyspieszenie procesów sekularyzacji (laicyzacji) w naszym kraju w najbliższych latach. Mogą one dotyczyć zarówno rozpadu więzi z religią i Kościołem (indyferentyzm religijny, ateizm), jak i - przede wszystkim - pogłębiania się subiektywizacji, selektywizacji

I. Borowik, Religijność w Polsce okresu transformacji - na tropach zmian, [w:] Polska początku XXI wieku: przemiany kulturowe i cywilizacyjne, red. K. Frysztacki, P. Sztompka, Warszawa 2012, s. 340. 
i indywidualizacji wiary oraz dotyczyć zarówno treści dogmatycznych, jak i moralnych katolicyzmu, przede wszystkim pozycji społecznej Kościoła w życiu publicznym.

$\mathrm{Na}$ początku drugiej dekady XXI wieku spory o miejsce Kościoła katolickiego w życiu publicznym znowu nabrały na sile, a krytyka Kościoła, nawet religii, stała się bardziej agresywna niż na początku lat 90. ubiegłego wieku. W modernizującym się społeczeństwie polskim Kościół katolicki próbuje na nowo określić swoje stanowisko zarówno wobec instytucji życia publicznego, jak i w odniesieniu do poszczególnych ludzi i grup społecznych. W 25 lat po upadku komunizmu proces redefinicji miejsca i roli Kościoła w demokratycznym społeczeństwie obywatelskim nie jest jeszcze zakończony, a może nawet daleki od zakończenia. Potrzebna byłaby swoista dyskusja „okrągłego stołu" dotycząca Kościoła i jego miejsca w życiu społecznym. Refleksja ta mogłaby być użyteczna zarówno dla Kościoła, jak i dla elit politycznych oraz dla całego społeczeństwa.

W kilku ostatnich latach zmienił się typ krytyki Kościoła i religii, zwłaszcza zaś obecności symboli religijnych w przestrzeni życia publicznego w naszym kraju. Z pewnych kręgów politycznych i ideologicznych wysuwane są postulaty usunięcia krzyży z miejsc publicznych, przesunięcia lekcji religii ze szkół do parafii, likwidacji tzw. Funduszu Kościelnego, usunięcia kapelanów z wojska i szpitali, legalizacji związków homoseksualnych, finansowania $\mathrm{z}$ funduszy państwowych zabiegów in vitro, aborcji i inne. Bulwersujące są przypadki wandalizmu i profanacje symboli religijnych, np. krzyży na cmentarzach, krzyża na Krakowskim Przedmieściu, obrazu Matki Boskiej Częstochowskiej, szopki bożonarodzeniowej i inne. Biskupi coraz częściej mówią o dyskryminacji katolików we własnym państwie, o zakłamywaniu przez media rzeczywistości społecznej, o dzieleniu społeczeństwa na lepszych i gorszych, o ograniczaniu wolności obywatelskich.

Niezależnie od tego, czy zgodzimy się z tymi diagnozami i interpretacjami całkowicie lub częściowo, czy też nie zgodzimy się wcale, tworzą one pewien klimat zagrożenia dla Kościoła i religii w naszym kraju. Kościół katolicki znalazł się (instytucjonalnie i nie tylko) w stanie defensywy. Różne siły społeczne i polityczne próbują usuwać go z życia publicznego, mamy do czynienia z silną falą laicyzmu, której skutki trudno przewidzieć. Zostało także przełamane pewne tabu, co wyraziło się w publicznej profanacji krzyża na Krakowskim Przedmieściu czy ostentacyjnym usuwaniu krzyży z miejsc publicznych, np. na uczelniach. Ważne jest w tym kontekście pytanie, jak Polacy (w tym przede wszystkim katolicy) będą reagować na nowe fakty podważające prawo obecności religii i Kościoła w przestrzeni życia publicznego.

Jak kształtują się ogólne i szczegółowe postawy i zachowania Polaków (zwłaszcza katolików) wobec Kościoła katolickiego? W jakim sensie można mówić o powolnych procesach emigracji katolików z Kościoła? Czy więcej jest elementów ciągłości czy zmiany? Czy scenariusz zagrożeń jest bardziej prawdopodobny niż scenariusz szans? Jak wiele (mniej czy więcej) potrzeba Kościoła w życiu publicznym społeczeństwa polskiego? Jak kształtuje się zaufanie społeczne do Kościoła katolickiego, jak Polacy oceniają jego zaangażowanie polityczne, jego kompetencje w sprawach społecznych i moralnych oraz obecność krzyży i innych symboli religijnych w przestrzeni życia publicznego? W ostatnich kilku latach dokonuje się powolny proces swoistego 
„schładzania się” silnych jeszcze w latach 80. ubiegłego wieku i na początku transformacji ustrojowej zaangażowań religijnych i kościelnych. Czy proces ten będzie charakteryzować się tendencją wzrostową?

Na niektóre z tych pytań usiłujemy odpowiedzieć w niniejszym artykule. Wychodzimy z założenia, że religijność z instytucjonalnym zabezpieczeniem odgrywa wciąż ważną rolę w kościelnym krajobrazie społeczeństwa polskiego i w sferze życia publicznego. W Polsce pozytywny stosunek do Kościoła ma ważne znaczenie jako wyznacznik osobistej religijności. Ten, kto nie ma zaufania do Kościoła, kto negatywnie ocenia go jako instytucję, wykazuje znaczną skłonność do ograniczania swojego udziału w praktykach religijnych, a nawet do osłabienia wiary. Religijność i kościelność są w Polsce z sobą bardzo silnie związane. Wśród socjologów polskich nie ma większych rozbieżności w ocenie rozmiarów sekularyzacji społeczeństwa, natomiast występują różnice w ocenie społecznej roli Kościoła, a co za tym idzie i w jej pojmowaniu. Dyskusje nad pozycją i rolą Kościoła katolickiego w społeczeństwie trwają, dalecy jesteśmy od jednoznacznych diagnoz, tym bardziej od zrozumienia i zaakceptowania modelowego funkcjonowania Kościoła w demokratycznym i pluralistycznym społeczeństwie. Finalne odpowiedzi mieszczą się w sferze hipotez i przypuszczeń.

\section{SPOŁECZNE ZAUFANIE DO KOŚCIOŁA KATOLICKIEGO}

Na najogólniejszym poziomie tożsamość katolicka jest traktowana jako własność Polaków - nieco ponad 90\% spośród nich przyznaje się do katolicyzmu. Kategorie więzi przynależności („jestem katolikiem”), więzi kościelnej („mam zaufanie do Kościoła”) i religijności („jestem wierzący”) nie pokrywają się w prosty sposób. Według sondażu CBOS w marcu 2000 roku 56,7\% badanych dorosłych Polaków deklarowało, że wierzy i stosuje się do wskazań Kościoła, 39,6\% - że wierzy na swój sposób, 1,3\% - że nie może powiedzieć, czy wierzy, czy też nie wierzy, $0,7 \%$ - że nie jest wierzące i nie interesuje się tymi sprawami, 0,4\% - że jest niewierzące, bo nauki Kościołów są blędne, 0,5\% inna odpowiedź, $0,8 \%$ - trudno powiedzieć ( $w$ marcu 2012 roku odpowiednio: 45,9\%, $47,3 \%, 2,2 \%, 1,7 \%, 1,5 \%, 0,3 \%, 1,0 \%$; w październiku 2014 roku - 39, $1 \%, 52,0 \%, 1,8 \%$, 2,2\%, 2,5\%, 0,4\%, 2,0\%). W latach 2000-2014 zmniejszał się wskaźnik deklarujących wiarę zgodnie z nauczaniem Kościoła (różnica 17,6\%) i wzrastał tych, którzy określali siebie jako wierzących na swój sposób (różnica 12,4\%). Proporcje „ortodoksów” i „nieortodoksów" uległy odwróceniu. W 2014 roku wierzący na swój sposób przeważali nad tymi, którzy wierzyli zgodnie z nauczaniem Kościoła (różnica 12,9\%). Tego rodzaju zmiany nie pozostają bez wpływu na zaufanie społeczne wobec Kościoła ${ }^{2}$.

W Polsce zaufanie do Kościoła katolickiego kształtowało się w okresie tzw. realnego socjalizmu na względnie wysokim poziomie. Po 1989 roku - wraz ze zmianą stosunków

\footnotetext{
Por. R. Boguszewski, Zmiany w zakresie wiary i religijności Polaków po śmierci Jana Pawta II, Komunikat z badań CBOS, nr BS/49/2012, Warszawa 2012, s. 12. Por. także: Wyniki badania „Aktualne problemy i wydarzenia”, Komunikat z badań CBOS, nr 293 (do użytku wewnętrznego), Warszawa 2014, s. 41 .
} 
ustrojowych i budową demokratycznego państwa - Kościół katolicki na nowo zaczął definiować swoje miejsce i rolę w transformującym się społeczeństwie. Pierwsze symptomy spadku zaufania do Kościoła pojawiły się w połowie 1990 roku, w okresie dyskusji nad projektem wprowadzenia religii do szkół publicznych. Najniższe pozytywne notowania działalności Kościoła jako instytucji społecznej skonstatowano - w świetle sondaży CBOS - w 1993 roku. Wydaje się, że ten radykalny spadek zaufania do Kościota związany byt ze zbyt dużm, w przekonaniu rodaków, wptywem Kościota na sprawy kraju, a wręcz z odczuwanym zagrożeniem przeobrażenia Polski w państwo wyznaniowe. $W$ drugiej potowie 1993 r. nastąita jednak zmiana spotecznego postrzegania Kościota, do której prawdopodobnie przyczynita się modyfikacja jego zewnętrznych dziatań. Spory dotyczace miejsca Kościota w życiu publicznym oraz ideologicznego ksztattu państwa stopniowo ucichty i z czasem udato się wypracować możliwy do zaakceptowania przez spoteczeństwo model stosunków państwo-Kościót. Przyczynito się to do odbudowania przez Kościót w latach 1993-1999 części utraconego prestiżu spotecznego. Poczawszy od $2000 \mathrm{r}$. obserwujemy okres stabilizacji opinii o Kościele katolickim. W ostatnich latach niewielkie zmiany stopnia aprobaty i dezaprobaty mają charakter bardzo krótkotrwaty ${ }^{3}$.

Niektórzy socjologowie wiązali proces zmniejszania się autorytetu Kościoła w sferze publicznej z takimi przyczynami, jak: sposób wprowadzenia religii do szkół, reprywatyzacyjne inicjatywy Kościoła i poszczególnych zakonów, niefortunne wypowiedzi i działania niektórych hierarchów Kościoła w czasie kampanii wyborczych, zaangażowanie Kościoła i środowisk katolickich w walkę o ustawę antyaborcyjną, zaangażowanie Kościoła w debatę konstytucyjną, walka o ratyfikację konkordatu ${ }^{4}$. Zdecydowana większość tych uregulowań prawnych, ustawowych i wykonawczych, inspirowanych bezpośrednio lub pośrednio aksjologią Kościoła katolickiego, dotyczyła pierwszej połowy lat 90. Wprowadzenie tych zmian normatywnych wywołało zróżnicowane reakcje opinii publicznej. Spadek zaufania do Kościoła katolickiego był analogiczny do spadku zaufania do innych instytucji życia publicznego. W warunkach radykalnych przemian ekonomicznych, politycznych i społecznych obniżało się w społeczeństwie polskim zaufanie do partii politycznych, parlamentu, senatu, związków zawodowych itp. Relatywny spadek zaufania do Kościoła po 1989 roku był związany między innymi z tym, że nie odgrywał on już tak ważnej jak dawniej roli w jednoczeniu narodu.

W świetle sondaży CBOS i TNS OBOP wydaje się uzasadniony wniosek, że ogólne oceny społecznej działalności Kościoła, po okresie pewnego kryzysu w latach 1991-1993, stają się jakby nieco bardziej przychylne. Można by przyjąć jako bardzo wiarygodną tezę sformułowaną na podstawie wyników sondaży realizowanych przez OBOP: Najwyższy jest odsetek osobistego zaufania respondentów do Kościota. Utrzymuje się on na poziomie ponad siedemdziesięciu procent. Niespetna potowa Polaków popiera potrzebę stosowania przez wtadze państwowe zasad nauki spotecznej Kościoła. Blisko dwie trzecie

R. Boguszewski, Religia i religijność Polaków w zmieniającym się spoteczeństwie, [w:] Życie po zmianie. Warunki życia i satysfakcje Polaków, red. K. Zagórski, Warszawa 2009, s. 174-175.

4 M. Grabowska, Religijność i Kościót w procesie transformacji w Polsce, [w:] Pierwsza dekada niepodlegtości. Próba socjologicznej syntezy, red. E. Wnuk-Lipiński, M. Ziółkowski, Warszawa 2001, s. 175-176. 
uważa, ̇̇e udziat Kościota w życiu politycznym kraju jest za duży. Można więc powiedzié,, że Polacy maja generalnie zaufanie do Kościota katolickiego, niechętnie natomiast widza jego zaangażowanie w życiu politycznym, szczególnie to bezpośrednie ${ }^{5}$. Deklarowane zaufanie wobec Kościoła podlega ustawicznym wahaniom w zależności od zmieniającego się kontekstu społeczno-politycznego i społeczno-kulturowego.

Od pierwszej dekady XXI wieku badacze opinii publicznej odnotowują powolny spadek zaufania społecznego wobec Kościoła. Według sondażu CBOS z marca 2010 roku $68 \%$ badanych dorosłych Polaków oceniało pozytywnie działalność Kościoła rzymskokatolickiego, 23\% - negatywnie; w marcu 2012 roku odpowiednio: $61 \%$ i $28 \%$; w marcu 2014 roku - 62\% i 29\%; w październiku 2014 roku - 58\% i 27\% (pozostali - „trudno powiedzieć”). Działalność Kościoła w większym stopniu aprobowali najmłodsi respondenci, osoby mające wykształcenie podstawowe, mieszkańcy wsi, zaangażowani w praktyki religijne oraz deklarujący prawicową orientację polityczną ${ }^{6}$. W październiku 2014 roku 11,9\% badanych dorosłych Polaków oceniało działalność Kościoła katolickiego zdecydowanie dobrze, 44,9\% - raczej dobrze, 18,7\% - raczej źle, 8,3\% - zdecydowanie źle, 14,8\% - trudno powiedzieć, i 1,4\% - odmowa odpowiedzi ${ }^{7}$.

Wysokie wskaźniki zaufania do Kościoła odnotowano w sondażu Instytutu Badania Opinii GfK Polonia w grudniu 2010 roku, przeprowadzonego na zlecenie dziennika „Rzeczpospolita”. W całej zbiorowości Polaków powyżej 15. roku życia 57\% badanych deklarowało pełne zaufanie do papieża, $26 \%$ - zaufanie, ale w ograniczonym zakresie, 9\% - brak zaufania, 5\% - nie wiem, i 3\% - odmowa odpowiedzi; zaufanie do Prymasa Polski odpowiednio - 43\%, 30\%, 14\%, 10\%, 3\%; zaufanie do biskupa diecezjalnego - 38\%, 35\%, 15\%, 9\%, 3\%; zaufanie do Episkopatu Polski - 34\%, 37\%, 17\%, 9\%, 3\%; zaufanie do proboszcza - 41\%, 30\%, 18\%, 7\%, 4\%. Respondenci oceniali dobrze działalność Kościoła w Polsce (według kategorii „bardzo dobrze” lub „dobrze”) w dziedzinie dbałości o liturgię - 80\% badanych, o język homilii - 72\%, listy pasterskie $-70 \%$, pracę duszpasterską - 73\%, działalność charytatywną - 72\%, relacje duchowieństwa ze świeckimi - 65\%, aktywność publiczną duchowieństwa - 63\%, aktywność publiczną świeckich katolików - 62\%. W całej zbiorowości $22 \%$ badanych zgadzało się zdecydowanie ze stwierdzeniem, że Kościół nie jest konieczny do tego, żeby być człowiekiem wierzącym, 36\% - raczej się zgadzało, 25\% - raczej się nie zgadzało, 9\% - zdecydowanie się nie zgadzało, i 8\% - nie wiem (informacje uzyskane w GfK Polonia).

Sondaż TNS OBOP z listopada 2010 roku dostarczył wielu interesujących danych dotyczących postaw Polaków wobec Kościoła katolickiego. Wśród ogółu badanych 19\% deklarowało w zdecydowany sposób zaufanie do Kościoła katolickiego, 47\% - raczej tak, 18\% - raczej nie, 11\% - zdecydowanie nie, i 5\% - trudno powiedzieć (w 1994 roku zaufanie do Kościoła - 71\% badanych, brak zaufania - 26\%, trudno powiedzieć

5 Postawy Polaków wobec Kościota i Konkordatu w lutym i marcu 1997 roku, Komunikat z badań OBOP (marzec 1997), Warszawa 1997, s. 9.

6 M. Feliksiak, Oceny instytucji publicznych, Komunikat z badań CBOS, nr BS/141/2014, Warszawa 2014, s. 5-6.

Wyniki badania „Aktualne problemy i wydarzenia”, Komunikat z badań CBOS, nr 293 (do użytku wewnętrznego), Warszawa 2014, s. 7. 
- 3\%). Udział Kościoła katolickiego w życiu politycznym kraju 27\% ankietowanych Polaków uznało za zdecydowanie za duży, 39\% - raczej za duży, 25\% - taki, jaki powinien być, $2 \%$ - raczej za mały, $1 \%$ - zdecydowanie za mały, i $6 \%$ - trudno powiedzieć. Równocześnie 45\% respondentów było zdania, że władze państwowe powinny kierować się zasadami społecznej nauki Kościoła katolickiego, 42\% - że nie powinny, i 13\% - trudno powiedzieć. W całej zbiorowości dorosłych Polaków 39\% badanych uważało, że to dobrze, iż państwo zwróciło Kościołowi ziemię i nieruchomości przejęte przez państwo w okresie PRL, a 39\% uważało, że to źle (22\% - trudno powiedzieć) ${ }^{8}$.

Stosunkowo pozytywny obraz relacji wiernych z ich Kościołem (nieco mniej niż 60\% wyrażało o nim przychylne opinie) - podlegający w XXI wieku tylko niewielkim zmianom negatywnym - nie wyklucza postaw krytycznych i zdystansowanych wobec tej instytucji. Krytyka Kościoła od początku transformacji ustrojowej w społeczeństwie polskim dotyczyła takich spraw, jak: nadmierne przywiązanie księży do dóbr materialnych, troska o odzyskanie utraconych w czasach komunistycznych przywilejów, nadmierne wpływy w społeczeństwie, „mieszanie się” do polityki, konserwatywna moralność i próby narzucania jej całemu społeczeństwu między innymi poprzez ustawodawstwo państwowe, skandale niektórych biskupów i księży. W niektórych środowiskach społecznych upowszechnia się niepokój o zakres ingerencji instytucji kościelnych w życie społeczne i polityczne w naszym kraju. Wciąż podtrzymuje się zarzuty o wysoce upolitycznionym Kościele, o jego wpływach we wszystkich dziedzinach życia, a nawet o Kościele jako superpartii?. Silne zaangażowanie Kościota w politykę, znajdujące odzwierciedlenie w pogladach wiernych, niepotrzebnie narzuca kontekst religijny na dokonujace sie $w$ systemie demokratycznym dyskusje i spory, nadto miast taczyć gtęboko dzieli ${ }^{10}$.

Krytyka dotyczy znacznie częściej Kościoła katolickiego jako instytucji, rzadko zaś odnosi się do przekonań religijnych. Wiele wskazuje na to, że na przełomie pierwszej i drugiej dekady XXI wieku coraz wyraźniej rozpoczyna się powolny kryzys zaufania do Kościoła jako instytucji społecznej, a częściowo i moralnej. Krytyka Kościoła dotyczy przede wszystkim publicznej działalności Kościoła i powoli przyczynia się do tworzenia swoistej kultury cynizmu i nieufności wobec niego. Jeżeli nawet te opinie i poglądy, a nawet uprzedzenia, nie zawsze odzwierciedlają rzeczywisty obraz Kościoła, to nie są one bez znaczenia dla kształtowania się opinii o Kościele w całym społeczeństwie, bo jest on właśnie takim, jakim się ludziom wydaje. Część zdystansowanych katolików uważa, że Kościół katolicki nie daje odpowiedzi na pytania, które są dla nich w życiu ważne. Niechęć czy obojętność wobec Kościoła współtworzą niektóre media opiniotwórcze, które kształtują poglądy o politycznej i społecznej ekspansji Kościoła katolickiego w społeczeństwie polskim. Krytyka, a nawet otwarta niechęć do Kościoła ujawniają się szczególnie wśród użytkowników Internetu.

Opinie Polaków o Kościele 2010, Komunikat z badań TNS OBOP (grudzień 2010), Warszawa 2010, s. 2-8.

9 M. Jarosz, Jaka Polska? [Wstęp], [w:] Polacy we wspólnej Europie. Dysproporcje materialne i spoteczne, red. M. Jarosz, Warszawa 2011, s. 24-25.

10 K. Szafraniec, Mtodzi 2011, Kancelaria Prezesa Rady Ministrów, Warszawa 2011, s. 379-380. 
Kościół katolicki w Polsce należy w dalszym ciągu do tych instytucji życia publicznego, które cieszą się największym zaufaniem społecznym, mimo że większość Polaków uważa, iż posiada on zbyt wielkie wpływy w społeczeństwie i nadmiernie włącza się bezpośrednio w spory polityczne, a nawet usiłuje oddziaływać na decyzje władz państwowych. Opinie przychylne o działalności Kościoła ponad dwukrotnie przeważają nad opiniami negatywnymi. Większy jest zakres przyzwolenia społecznego na wpływ religii na życie publiczne, poprzez zasady i wartości moralne, które należy uwzględniać w społeczeństwie. Społecznie zaufanie do Kościoła podlega ustawicznym wahaniom, a w ostatnich latach powoli wchodzi w fazę zniżkową. Wydaje się, że obecnie wchodzimy w okres obniżania się autorytetu społecznego Kościoła katolickiego, co jest niewątpliwie związane z licznymi kontrowersjami wokół lustracji w Kościele oraz nagłaśnianymi przez media domniemanymi czy rzeczywistymi skandalami w środowiskach osób duchownych. Nie bez znaczenia są powolne, ale postępujące procesy spontanicznej i pełzającej sekularyzacji. Proces ten ulegnie przyspieszeniu, jeżeli tego rodzaju wydarzenia będą się nasilać i zostanie w końcu przekroczony „próg wytrzymałości” ludzi wierzących.

Scenariusz irlandzki nie jest wykluczony. Trzeba jednak podkreślić, że krytyka Kościoła i odchodzenie od niego niektórych katolików nie są podyktowane tylko jakimiś konkretnymi wydarzeniami, które niespodziewanie wyszły na jaw. Na ogół przyczyny wyjścia z Kościoła są wielorakie, a ich tłem jest także postępująca, chociaż powolna, sekularyzacja społeczeństwa. Jeżeli nawet w przyszłości nie dojdzie w Polsce do masowej emigracji katolików z Kościoła, to z pewnością ten Kościół będzie coraz bardziej zróżnicowany, pluralistyczny i wielobarwny, a katolicy nie będą tworzyć jednolitego bloku nie tylko w sprawach społeczno-politycznych, ale i religijnych. W odniesieniu do działalności Kościoła katolickiego w społeczeństwie polskim warto byłoby przeprowadzić dokładniejsze analizy w ramach subdyscypliny socjologicznej nazywanej „socjologią grzechu” lub „socjologią zła”.

Być może zaangażowanie się Kościoła instytucjonalnego, w tym szczególnie Radia Maryja, w kampanie polityczne przed wyborami parlamentarnymi i prezydenckimi będzie powodować spadek społecznego zaufania do Kościoła, podobnie jak na początku lat 90. Doświadczenie okresu postkomunistycznego pokazuje, że Kościoły walczące o władzę i pozycję społeczną (a zwłaszcza polityczną) niszczą swoją moralną wiarygodność. Wydaje się, że znalezienie właściwej pozycji i roli w społeczeństwie pluralistycznym jest jeszcze dla Kościoła katolickiego w Polsce nieodrobioną lekcją. Nie jest on jednak instytucją wskazaną na powolny schyłek czy konanie, bez szans na ratunek. Wbrew pesymistycznym prognozom nie staje się on wartością , antykwaryczną”. Zaufanie przyznawane przywódcom religijnym przewyższa w społeczeństwie polskim w sposób wyraźny zaufanie wobec polityków i wielu instytucji życia publicznego. Deklarowane zaufanie do Kościoła katolickiego w ostatnich miesiącach nieznacznie spada, nie ma jednak podstaw do ogłaszania paniki moralnej. Uogólnione zaufanie do Kościoła może być jednak osłabione, a nawet zniszczone zarówno przez siły zewnętrzne (ideologie wrogie Kościołowi), jak i wewnętrzne w Kościele (przez samych duchownych).

Dla Kościołów w krajach postkomunistycznych, w tym i w Polsce, istnieje ważny problem ustalenia ich relacji z państwem. Według Detlefa Pollacka próby wpływania na 
decyzje wyborcze obywateli, a nawet odgórne narzucanie reguł moralnych bardziej szkodzi, niż przynosi korzyść Kościołowi. Współczesne społeczeństwa są funkcjonalnie zróżnicowane i Kościoły powinny respektować autonomię sfery pozareligijnej. Jeżeli Kościoły chcą dostrzegać problemy ludzi i reprezentować je publicznie, muszą to robić w inny sposób niż w okresie komunizmu. Nie mogą już pełnić bezpośrednio funkcji politycznych i muszą zachować pewien dystans wobec spraw politycznych. Nie znaczy to, że powinny całkowicie odcinać się od problemów społecznych, ekonomicznych czy politycznych, ale powinny się troszczyć o to, by nie wzbudzać podejrzeń o reprezentowanie czyichś interesów politycznych albo o to, że wspierają inicjatywy państwa. W przeciwnym razie zostaną uznane za jedną ze stron w dyskursie politycznym albo w ogóle za instytucję władzy. Reakcją ludzi jest sceptycyzm wobec Kościoła jako instytucji władzy. Z doświadczeń krajów postkomunistycznych wynika, że bliskość Kościoła i państwa do pewnego stopnia delegitymizuje działania kościelne ${ }^{11}$.

Według wielu socjologów Kościół państwowy, będący swoistym przedłużeniem aparatu państwowego, był i jest istotnym czynnikiem sekularyzacyjnym w społeczeństwie (np. w krajach skandynawskich). Silna identyfikacja Kościoła z władzą przyczyniała się do swoistej „alienacji” w Kościele i osłabienia roli religii w życiu jego członków. Nawet w tak katolickim kraju jak Polska - zaznacza Detlef Pollack - próby wywierania przez Kościół wpływu na decyzje wyborcze obywateli, a nawet żądanie posłuszeństwa w sprawach moralnych, przyniosły więcej szkód niż pożytku. Jeżeli nawet na początku lat 90. wielu ludzi oczekiwało od Kościołów spełniania funkcji społecznych, to już wkrótce ich postawy uległy zmianie i w znacznej mierze zakwestionowali oni wpływ Kościołów na politykę i rządy czy preferencje wyborcze obywateli, upodabniając się do tych, które od dawna upowszechniły się w Europie Zachodniej. Takie jest doświadczenie wielu Kościołów Europy Środkowo-Wschodniej po upadku państwowego socjalizmu ${ }^{12}$.

Należy się także liczyć z procesem przemian, który wystąpił już w Europie Zachodniej - że wierni będą częściej wysuwać różnego rodzaju oczekiwania i roszczenia wobec Kościoła instytucjonalnego, nie będą godzić się na traktowanie ich jako jego członków drugiej kategorii podporządkowanych dyrektywom z „góry”. Wielu katolików, zwłaszcza ludzi młodych, wyraża przekonanie, że Kościół katolicki nie potrafi przekonująco odpowiedzieć na palące problemy społeczne, ekonomiczne i polityczne, a także na problemy i pytania, nadzieje i lęki współczesnej młodzieży. W sferze świadomości indywidualnej sumienie osobiste zastępuje powoli zewnętrzne autorytety, zarówno w dogmatyce, jak i etyce chrześcijańskiej. Wiele przemawia za prognozą dłuższego spadku zaufania społecznego do Kościoła katolickiego. Nadchodzące lata będą określać dysonanse, konflikty i krytycyzm wobec Kościoła w społeczeństwie polskim.

Socjologowie religii w Polsce powinni ustawicznie stawiać sobie pytania zarówno o powody i przyczyny zmniejszania się zainteresowania Kościołem, jak i o jego zwrotny

11 D. Pollack, Das Verhältnis von Religion und Politik in den postkommunistischen Staaten Ostmittel- und Osteuropas und seine Auswirkungen auf die Vitalität des religiösen Feldes, [w:] Politik und Religion, Hrsg. M. Minkenberg, U. Willems, Wiesbaden 2003, s. 453, Politische Vierteljahresschrift. Sonderheft, 33.

12 D. Pollack, Religion und Politik in den postkommunistischen Staaten Ostmittel-und Osteuropas, „Aus Politik und Zeitgeschichte" 2002, Vol. B 42-43, s. 18-22. 
wpływ na świadomość religijną Polaków. Religijność w Polsce jest w dalszym ciągu związana z konkretnymi Kościołami, chociaż nieco słabnie w warunkach modernizacji społecznej, tak ze względu na rosnący pluralizm wewnątrz Kościoła, jak i poza nim. W społeczeństwie polskim dominująca pozostaje religijność kościelna, a więc związana z Kościołami. Jeżeli nawet wielu Polaków uznaje teoretycznie możliwość bycia religijnym bez Kościoła, to w praktyce ci, którzy uczestniczą w życiu kościelnym, realizują praktyki kultowe i czują się emocjonalnie związani z Kościołem, są równocześnie bardziej religijni niż wierzący będący poza Kościołem. Indywidualne i instytucjonalne wymiary religijności nie stanowią u większości Polaków przeciwstawnych biegunów. Religijność w społeczeństwie polskim jest w dalszym ciągu określana przede wszystkim przez instytucje kościelne.

\section{KOŚCIÓŁ KATOLICKI A ZAANGAŻOWANIE POLITYCZNE}

Po 1989 roku ścierały się z sobą dwa skrajne, przeciwstawne sobie stanowiska. W myśl pierwszego „Kościół zrobił swoje” i powinien w „wolnej już Polsce usunąć się w cień”. Według drugiego - powinien jako uwiarygodniony w latach 80. ubiegłego wieku pełnoprawny element składowy społeczeństwa obywatelskiego jeszcze bardziej aktywnie uczestniczyć w życiu społecznym i politycznym oraz mieć prawo czynić to na specjalnych, uprzywilejowanych zasadach. Rafał Drozdowski osądza obydwa stanowiska jako niebezpieczne dla rozwoju społeczeństwa obywatelskiego w naszym kraju. Pierwsze dlatego, że wypycha instytucję Kościoła poza granice społeczeństwa obywatelskiego i tym samym niejako z góry pozbawia go prawa głosu. Drugie dlatego, że stawia pod znakiem zapytania równość instytucji obywatelskich i równość wszystkich obywatelskich reprezentacji ${ }^{13}$. Miejsce i rola Kościoła katolickiego w społeczeństwie obywatelskim, czy szerzej w sferze życia publicznego, jest i będzie przedmiotem sporów i dyskusji, a sam Kościół jest i będzie przez niektórych etykietowany jako „antymodernistyczny”.

Zaangażowanie się Kościoła w życie publiczne, szczególnie zaś w życie polityczne, należy do problemów niezwykle często dyskutowanych w ostatniej dekadzie XX wieku i w pierwszej dekadzie XXI wieku. Ci, którzy uważają, że model obecności Kościoła w życiu publicznym z okresu tzw. realnego socjalizmu powinien być uznany za normę dla społeczeństwa pluralistycznego i demokratycznego, dość często protestują przeciwko wszelkim formom zwiększania obecności Kościoła w życiu publicznym i przestrzegają przed dążeniami do tworzenia państwa wyznaniowego, zdominowanego wpływami Kościoła katolickiego w społeczeństwie. Od początku lat 90. ubiegłego wieku trwa swoista moda na wyolbrzymianie społecznych i politycznych wpływów Kościoła katolickiego, podkreślanie jakiejś ofensywy instytucji kościelnych i osób z nim związanych, zwłaszcza w zakresie spraw legislacyjnych, a także dostrzeganie niebezpieczeństwa katolickiego fundamentalizmu w naszym kraju (swoiste upowszechnianie strachu przed

13 R. Drozdowski, Demokratyczne spoteczeństwo obywatelskie w Polsce w obecnych warunkach funkcjonowania państwa, [w:] Religia i Kościót w spoteczeństwie demokratycznym i obywatelskim w Polsce. Między losem a wyborem, red. J. Baniak, Poznań 2012, s. 26. 
Kościołem). Lęki przed Kościołem i negatywne postawy wobec jego działalności w sferze publicznej ujawniają się w wielu krajach postkomunistycznych ${ }^{14}$.

Szczególnym przedmiotem krytyki Kościoła jest jego rzekome czy rzeczywiste zaangażowanie się w życie polityczne. Według niektórych socjologów mamy do czynienia w społeczeństwie polskim z wyraźnymi przejawami polityzacji religii, a nawet z szerokim włączaniem się duchowieństwa, a także struktur kościelnych do życia politycznego. Kościół ze swej strony podkreśla, że jego misja ma przede wszystkim charakter religijny, a nie polityczny, włącza się on w porządek społeczny z powodu implikacji, jakie jego religijna misja ma względem życia doczesnego. Pierwszą troską Kościoła jest wychowanie sumienia, a tym samym kształtowanie niezbędnej odpowiedzialności. Chodzi o wychowanie sumienia zarówno w dziedzinie etyki indywidualnej, jak i etyki społecznej. Człowiek współczesny świadomy swej wolności i niezależności względem wszelkich instytucji, traktujący instrumentalnie instytucje współczesne, jako służące zaspokajaniu indywidualnych potrzeb życiowych, usiłuje w podobny sposób traktować Kościół. Krytyka Kościoła stanowi stały, jakby normalny, element świadomości wielu ludzi współczesnych. Niekiedy nawet jest traktowana jako niezbędna część pluralistycznego dialogu społecznego, prowadząca do uzyskania właściwego konsensu co do miejsca i roli Kościoła w nowoczesnym społeczeństwie. Kościół katolicki uznawany jeszcze do niedawna za główną ostoję wartości narodowych i kulturowych, za gwarant ładu społecznego i moralnego jest dzisiaj postrzegany przez część Polaków raczej jako zagrożenie dla autentycznych wartości kultury, a nawet moralności.

Wiele opinii o Kościele - w świetle sondaży CBOS - utrzymuje się na względnie stałym poziomie. W latach 1999-2007 wskaźnik oceniających wpływ Kościoła na życie kraju według kategorii „bardzo duży” i „duży” kształtował się na poziomie od 68\% do 62\%. W 1999 roku 25\% badanych wskazało na jakieś dziedziny życia kraju, na które Kościół powinien mieć większy wpływ niż obecnie, w 2007 roku - 22\%; w 1999 roku tylko 5\% ankietowanych uważało, że Kościół powinien mieć większy niż dotychczas wpływ na życie kraju, w 2007 roku - 10\% (raczej mniejszy i zdecydowanie mniejszy odpowiednio: 61\% i 50\%). Zdecydowana większość Polaków wyraża opinię, że Kościół nie powinien wypowiadać się w sprawach politycznych (w 1999 roku - 77\%, 2007 roku - 86\%). Także w okresie PRL przeważała opinia, że Kościół nie powinien wypowiadać się w sprawach politycznych (w 1988 roku - 57\%) ${ }^{15}$.

Sondaże opinii publicznej i badania socjologiczne dostarczają wielu, nie zawsze zgodnych z sobą, wyników na temat poglądów Polaków w zakresie uznania uczestnictwa Kościoła katolickiego w życiu społecznym, a zwłaszcza politycznym. Z danych sondażowych opisanych wyżej wynika, iż udział Kościoła katolickiego w życiu politycznym kraju ponad połowa Polaków uznaje za duży. Równocześnie opinia publiczna na temat tego, czy władze państwowe powinny kierować się zasadami społecznej nauki

14 M. Kerševan, Europejczycy jutra. Chrześcijanie bez Kościota - ludzie bez wiary, „Przegląd Powszechny” 2000, nr 11 (numer specjalny), s. 38-45.

15 B. Roguska, Opinie o dziatalności Kościota, Komunikat z badań CBOS, nr BS/37/2007, Warszawa 2007, s. 1-10. 
Kościoła, jest bardzo podzielona (według cytowanego na s. XX sondażu TNS OBOP $45 \%$ było zdania, że powinny, $42 \%$ - że nie powinny). Podobną sprzeczność i podział opinii publicznej można zauważyć w ocenie zwrotu Kościołowi ziemi i nieruchomości przejętych przez państwo w okresie PRL.

W sondażu Europejskich Systemów Wartości (EVS) z 2008 roku postawiono Polakom między innymi następujące pytanie: „Czy sądzi Pan(i), że Kościół ma wpływ na politykę w Polsce, czy też nie”. Uzyskano następujące wyniki: zdecydowanie tak - 31,9\%, raczej tak $-46,5 \%$, raczej nie $-11,9 \%$, zdecydowanie nie $-2,1 \%$, trudno powiedzieć $6,0 \%$, brak odpowiedzi - 1,7\%. Odpowiedź potwierdzającą wpływ Kościoła na politykę w Polsce zadeklarowało $78,4 \%$ badanych dorosłych Polaków. W całej zbiorowości dorosłych Polaków 15,6\% badanych zgadzało się z twierdzeniem, że politycy, którzy nie wierzą w Boga, nie powinni zajmować stanowisk publicznych; 67,4\% - że Kościół nie powinien wpływać na decyzje rządzących; $74,4 \%$ - że księża nie powinni ludziom mówić, jak mają głosować; $24,1 \%$ - że lepiej byłoby dla Polski, gdyby więcej ludzi głęboko wierzących obejmowało urzędy państwowe (odpowiedź „ani się zgadzam, ani się nie zgadzam” odpowiednio: 26,8\%, 18,7\%, 15,3\%, 39,3\%; odpowiedź „nie zgadzam się" lub „zdecydowanie nie zgadzam się” odpowiednio: 53,4\%, 10,2\%, 7,0\%, 29,8\%). Pozostali respondenci byli niezdecydowani lub nie udzielili odpowiedzi ${ }^{16}$.

W ogólnopolskim sondażu pt. „Kościół katolicki w świadomości Polaków”, zrealizowanym w 2002 roku przez Instytut Statystyki Kościoła Katolickiego SAC, 66,6\% badanych twierdziło, że Kościół katolicki miesza się do polityki, 22,7\% - nie zgadzało się z tym, a 10,4\% - nie miało zdania w tej sprawie. Pogląd o mieszaniu się Kościoła do polityki częściej wyrażały osoby do 34. roku życia, o złej sytuacji materialnej, bezrobotni, słabo praktykujący i o poglądach lewicowych. W całej zbiorowości 34,6\% respondentów twierdziło, że księża powinni wypowiadać się na temat polityki rządu, 57,3\% - że nie powinni, a 7,9\% - trudno powiedzieć. Nawet wśród głęboko wierzących $(44,1 \%)$ i systematycznie praktykujących mniej niż połowa ankietowanych oczekiwała takich wypowiedzi. Jako przykłady ingerowania Kościoła w sprawy polityczne podawano akcje przedwyborcze księży przed wyborami parlamentarnymi i prezydenckimi. Znamienne jest to, że aż $63,2 \%$ badanych udzieliło odpowiedzi twierdzącej na pytanie, czy katolik może głosować na kandydata do władz publicznych, który deklaruje się jako niewierzący, 23,0\% - nie powinien, a 13,5\% - trudno powiedzieć ${ }^{17}$.

W październiku 2011 roku - według sondażu CBOS - tylko 2,2\% badanych dorosłych Polaków twierdziło, że w ich parafii księża podczas kazań bardzo często ujawniają swoje sympatie partyjne lub sugerują, które ugrupowanie polityczne należy popierać lub na kogo głosować w wyborach; 5,0\% - dość często, 14,3\% - tak, ale tylko sporadycznie, $61,3 \%$ - nie, nigdy, 16,3\% - trudno powiedzieć, $0,9 \%$ - odmowa

16 Kwestionariusz wywiadu EVS 2008, [w:] Wartości i zmiany. Przemiany postaw Polaków w jednoczaccej się Europie, red. A. Jasińska-Kania, Warszawa 2012, s. 335, 354; M. Marody, S. Mandes, Przemiany polskiej religijności, [w:] Wartości i zmiany..., s. 200.

17 A. Ochocki, Kościót katolicki a sprawy publiczne w Polsce, [w:] Kościót katolicki na początku trzeciego tysiaclecia w opinii Polaków, red. W. Zdaniewicz, S.H. Zaręba, Warszawa 2004, s. 211-214, Studia Socjologiczno-Religijne, nr 23. 
odpowiedzi ${ }^{18}$. Większość badanych dementuje tezę, by w ich parafiach podczas kazań księża ujawniali swoje sympatie polityczne, sugerowali, które ugrupowania polityczne należy popierać, czy nakłaniali do głosowania w wyborach na konkretnych kandydatów. Agitacja polityczna księży częściej jest dostrzegana w miastach (od 29\% do $32 \%$ ) niż na wsiach (20\%), podobnie w Polsce południowo-wschodniej i centralnej, jak i północno-zachodniej ${ }^{19}$. Powszechna jest krytyczna ocena przedwyborczej aktywności księży, którzy podpowiadają wiernym, jak mają głosować w wyborach.

Pozytywne opinie o działalności Kościoła katolickiego deklaruje nieco mniej niż 60\% Polaków, ale wyraźna większość domaga się ograniczenia jego wpływów w życiu publicznym, zwłaszcza $\mathrm{w}$ formie bezpośredniej ingerencji, bądź uważa te wpływy za zbyt duże. Co jakiśs czas wybuchają spory o miejsce i rolę Kościoła katolickiego w życiu publicznym naszego kraju, co oznacza, że sam problem nie został w sposób wystarczający dla wielu rozwiązany. Wydaje się, że Kościół katolicki w Polsce powinien jeszcze wyraźniej ukierunkować się na odnalezienie swojego miejsca i roli w społeczeństwie obywatelskim. Kształtowanie zaufania społecznego ma fundamentalne znaczenie dla długofalowego rozwoju Kościoła w naszym kraju. Opinie nawołujące do swoistej „abstynencji" Kościoła w dziedzinie politycznej dominowały wśród Polaków, do pewnego stopnia niezależnie od cech demograficznych i społecznych. Osoby słabo lub w ogóle niezwiązane z Kościołem w nieco większym stopniu domagały się od niego powstrzymania od ingerencji w sprawy polityczne. W sferze działalności politycznej rola Kościoła nie jest przyjmowana bezkrytycznie, wręcz przeciwnie - jest oceniana krytycznie, niekiedy nawet nadkrytycznie.

Katolicyzm w Polsce nie jest tak słaby, jak chcieliby go widzieć jego przeciwnicy, ani tak silny jak mniemają jego obrońcy, skłonni uznawać katolicyzm polski za swoisty „towar” eksportowy do Unii Europejskiej. Z pewnością tylko dla zdecydowanej mniejszości Polaków Kościół katolicki wydaje się przestarzały, a to, co on proponuje, jest niepotrzebne („przeterminowany towar”). Niemniej jednak w pierwszej dekadzie XXI wieku Kościół katolicki tracił stopniowo swój wpływ normatywny na politykę oraz w coraz mniejszym zakresie wspierał reguły kontroli społecznej. Nie znaczy to jednak, że nie wpływa już na zachowania codzienne Polaków, ale treści religijne odłączają się od struktur władzy politycznej. W świecie społecznym religia nie należy do tzw. struktur silnych.

Krytyka Kościoła przyczynia się niejednokrotnie do tworzenia się swoistej kultury cynizmu i nieufności wobec niego. Jeżeli nawet te opinie i poglądy, a nawet uprzedzenia, nie zawsze odzwierciedlają rzeczywisty obraz Kościoła, to nie są one bez znaczenia dla kształtowania się opinii o Kościele w całym społeczeństwie, bo jest on właśnie takim, jakim się ludziom wydaje. Niechęć czy obojętność wobec Kościoła współtworzą niektóre media opiniotwórcze, które kształtują poglądy o politycznej i społecznej

18 Wyniki badania „Aktualne problemy i wydarzenia”, Komunikat z badań CBOS, nr 258 (do użytku wewnętrznego), Warszawa 2011, s. 28.

19 N. Hipsz, Polaków obraz rzeczywistości parafialnej, Komunikat z badań CBOS, nr BS/144/2011, Warszawa 2011, s. 14-15. 
ekspansji Kościoła katolickiego w społeczeństwie. Krytyka, a nawet otwarta niechęć do Kościoła ujawnia się szczególnie wśród użytkowników Internetu. Jeżeli nawet teoretyczny ateizm i antyklerykalizm to dwie nieco odmienne postawy, to w Polsce - w wymiarze empirycznym - w wielu przypadkach nakładają się one na siebie.

W obawie przed zarzutami zaangażowania politycznego coraz rzadziej komentuje się ważne wydarzenia bieżące z punktu widzenia społecznego nauczania Kościoła. Stanowisko Kościoła jest wyraźne w zagadnieniach związanych z obroną małżeństwa, w kwestiach bioetycznych, ale w wielu innych sprawach głos Kościoła jest niezbyt donośny. Coraz więcej jest oznak świadczących o tym, że Episkopat Polski wycofał się w znacznym stopniu z dyskursu publicznego w ważnych sprawach mieszczących się w ramach troski o dobro wspólne. Wycofywanie się ze sfery politycznej nie powinno oznaczać milczenia w sprawach publicznych związanych z moralnością, zwłaszcza na poziomie ogólnych zasad etycznych. Trzeba jednak w miarę precyzyjnie rozróżniać kompetencje Kościoła i państwa jako społeczności autonomicznych. Nieprzestrzeganie podziału tych kompetencji, czasem usprawiedliwione szczególnymi okolicznościami, zwykle jednak przynosi skutki odwrotne od zamierzonych.

W Polsce wskaźniki religijności sytuują się na wyższym poziomie niż wskaźniki kościelności (aprobata Kościoła i jego działalności). W odniesieniu do działalności Kościoła zaspokajającej potrzeby duchowe ludzi i w ogóle do aprobaty Kościoła (zaufanie) są one wyższe niż w aspekcie jego działalności społecznej i publicznej (np. politycznej). Zdecydowana większość Polaków nie życzy sobie, by Kościół angażował się w sprawy polityczne kraju. Ustosunkowanie się Polaków do Kościoła wpływa - bezpośrednio lub pośrednio - na kondycję religijną, moralną i społeczną parafii katolickich, opinie negatywne nie sprzyjają jej, opinie pozytywne wzmacniają tę kondycję. Wpływy i oddziaływania idą z pewnością i w odwrotnym kierunku, od parafii do Kościoła. Zmiana nastrojów społecznych wobec Kościoła i parafii może się utrzymywać na względnie stałym poziomie, ale może też szybko cofnąć się w jakimś kierunku.

\section{SPOŁECZNE KOMPETENCJE KOŚCIOŁA KATOLICKIEGO}

Na przełomie 1989 i 1990 roku wielu ludzi w Europie Środkowo-Wschodniej, w tym i w Polsce, oczekiwało, że Kościoły chrześcijańskie wypełnią powstałą wcześniej próżnię społeczno-moralną i będą pełnić wiele funkcji dających orientację życiową. Oczekiwano wypowiedzi Kościołów w sprawach społecznych, jak bezrobocie, ochrona środowiska, różne przejawy dyskryminacji i potrzeb ludzkich. Stosunkowo wysokie było zaufanie do Kościołów i wspólnot religijnych. W krótkim okresie po przełomie wielu zakwestionowało wpływ Kościołów na bieżącą politykę, na decyzje władz państwowych, preferencje wyborcze ludzi wierzących i sytuowało działalność Kościoła raczej w sferze spraw duchowych. Następowała powolna redefinicja kompetencji Kościoła w sprawach społecznych.

Wciąż utrzymuje się na znacznym poziomie lub nawet powiększa sięzbiorowość tych, którzy uważają się za katolików, jednak charakteryzują się słabą więzią z Kościołem lub 
w ogóle są jej pozbawieni. W Polsce wielu katolików, nawet związanych z Kościołem, w wielu ważnych kwestiach społecznych i etycznych nie uznaje norm moralnych głoszonych przez Kościół. Kształtują oni swoją indywidualną religijność niekiedy w opozycji do zinstytucjonalizowanych wymiarów katolicyzmu. Krytyczne opinie, zwłaszcza młodzieży, o Kościele wynikają zapewne z wielu przyczyn, między innymi dystansowania się wobec kościelnego nauczania na temat etyki seksualnej, aborcji, środków antykoncepcyjnych, homoseksualizmu, a także negatywnych opinii o ingerowaniu Kościoła w sprawy publiczne, zwłaszcza o charakterze politycznym. Uogólnione zaufanie do Kościoła, niepozbawione pewnych symptomów krytycyzmu, jest spowodowane nie tylko procesem pluralizacji i indywidualizacji w społeczeństwie, ale i działalnością samych instytucji społeczno-politycznych, a nawet kościelnych (w tym i hierarchii kościelnej).

Badania socjologiczne i sondaże opinii publicznej dostarczają w kwestii kompetencji Kościoła rozmaite wyniki, nie zawsze w pełni konkluzyjne. Kompetencje Kościoła są oceniane w odniesieniu do kilku dziedzin życia ludzkiego. Być może stawiane pytania nie zawsze są precyzyjne, nie dają podstawy do ustalenia ogólnych nastawień i ocen działalności społecznej Kościoła w opinii młodszego i starszego pokolenia Polaków. Działalność Kościoła na różnych szczeblach instytucjonalnych ma charakter publiczny, pozostaje pod uważną obserwacją ludzi w środowiskach lokalnych, jest komunikowana i oceniana w środkach społecznego przekazu.

W społeczeństwach pluralistycznych czy pluralizujących się (np. Polska) oferta Kościoła jest jedną z wielu, spośród których można dowolnie dokonywać wyborów, zgodnie z tym, co uznaje się za wartościowe i zasługujące na akceptację. Na tle niepełnego zaufania do Kościoła katolickiego jako instytucji religijnej i społecznej ważne są pytania o przypisywane mu kompetencje w sprawach społecznych, moralnych i duchowych. Być może na tej płaszczyźnie ujawnią się w sposób bardziej wyraźny różne przejawy spadku zaufania do Kościoła, a może i pierwsze symptomy wielowymiarowego kryzysu. Oczekiwania kierowane pod adresem Kościoła są różnorodne. Oprócz funkcji religijnych pełni on lub może pełnić rozmaite funkcje społeczno-kulturowe.

W ramach badań międzynarodowych nad wartościami ustalono, że w Polsce w 1990 roku $80 \%$ badanych dorosłych Polaków deklarowało, iż Kościoły dają adekwatne odpowiedzi na problemy moralne i potrzeby indywidualne, w 2000 roku - 66\%, i w $2006-$ $66 \%$; problemy rodziny odpowiednio $-81 \%, 64 \%, 65 \%$; potrzeby duchowe $-89 \%$, $83 \%, 84 \%$; problemy społeczne $-52 \%, 41 \%, 46 \%{ }^{20}$. Przeciętny wskaźnik odpowiedzi pozytywnych dla czterech sytuacji kształtował się w 1990 roku na poziomie 75,5\%, w 2000 roku - 63,5\%, i w 2006 roku - 65,2\%. Uznawane przez dorosłych Polaków kompetencje Kościoła w omawianych sprawach społecznych, moralnych i duchowych uległy w latach 1990-2006 nieznacznemu zmniejszeniu (o około 10\%).

Sondaże Europejskich Systemów Wartości odnotowują w Polsce spadek uznania dla udzielanych przez Kościół katolicki odpowiedzi należących do różnych obszarów życia społecznego. W 1990 roku 80,0\% badanych dorosłych Polaków deklarowało, że

20 Changing Human Beliefs and Values, 1981-2007, [w:] A Cross-Cultural Sourcebook based on the World Values Surveys and European Values Studies, ed. R. Inglehart, Chichester 2010, s. 242-245. 
Kościół katolicki w Polsce daje właściwe odpowiedzi na pytania dotyczące potrzeb duchowych człowieka, 70,7\% - problemów życia rodzinnego, 67,2\% - moralnych problemów i potrzeb jednostki, 38,3\% - problemów społecznych i politycznych; w 1999 roku odpowiednio - 73,4\%, 55,5\%, 54,6\%, 31,8\%; w 2005 roku - 77,5\%, 59,6\%, 58,1\%, 39,3\%; w 2008 roku - 72,6\%, 50,2\%, 54,4\%, 31,0\%. Systematycznie spadała akceptacja oferowanych przez Kościół odpowiedzi na moralne problemy jednostki, problemy społeczne i polityczne, a zwłaszcza problemy rodzinne. Najniższy spadek odnotowano w przypadku odpowiedzi na problemy duchowe człowieka (różnica 7,4\% ${ }^{21}$. Przeciętny wskaźnik zbiorczy dla czterech sytuacji życia ludzkiego kształtował się w 1990 roku na poziomie 64,0\%, w 1999 roku - 53,8\%, w 2005 roku - 58,6\%, i w 2008 roku - 52,0\%. W latach 1990-2008 nastąpił spadek przyznawanych Kościołowi kompetencji w sprawach moralnych i społecznych o 12,0\%. Mniej Polaków uznaje za właściwe odpowiedzi Kościoła na problemy życia codziennego, ale wniosek, że świadczy to o postępującym procesie sekularyzacji i prywatyzacji religijności, wydaje się przedwczesny.

Według sondażu zrealizowanego na zlecenie Centrum Myśli Jana Pawła II w 2007 roku 43\% badanych będących w wieku 15-19 lat deklarowało, że Kościół katolicki w Polsce daje właściwe odpowiedzi na pytania dotyczące moralnych problemów i potrzeb jednostki, $46 \%$ - problemów życia rodzinnego, $65 \%$ - problemów duchowych człowieka, i 18\% - problemów społecznych (młodzież w wieku 20-29 lat odpowiednio: 44\%, 50\%, 72\%, 26\%). Przeciętny wskaźnik aprobaty kompetencji Kościoła w czterech ocenianych obszarach jego działalności kształtował się u młodzieży w wieku 15-19 lat na poziomie 43\%, w wieku 20-29 lat - 48\% ${ }^{22}$. Uogólniony wniosek z badań przeprowadzonych przez Centrum Myśli Jana Pawła II jest następujący: W ocenie Polaków Kościót dobrze odpowiada na oczekiwania ludzi w sferze duchowej, rodzinnej i moralnej, gorzej na oczekiwania dotyczace sfery spotecznej, a zwtaszcza politycznej. W przypadku tej ostatniej sfery można mówić nawet o ponadprzeciętnym, w porównaniu ze średniq europejska, krytycyzmie Polaków wobec bezpośredniego zaangażowania Kościota, zaskakującym $w$ świetle tego, jak wiele ze spotecznego nauczania Kościota faktycznie jest im bliskie ${ }^{23}$.

Badani w 2009 roku maturzyści z pięciu miast (Szprotawa, Puławy, Kraśnik, Dęblin i Gdańsk) odpowiadali na pytanie, czy Kościół w naszym kraju daje adekwatne i zadowalające odpowiedzi na problemy jednostki, młodzieży, warstw społecznych (rolnicy, robotnicy, inteligencja) i narodu. Biorąc pod uwagę odpowiedzi aprobujące bez zastrzeżeń i z małymi zastrzeżeniami działalność społeczną Kościoła katolickiego w 2009 roku, można powiedzieć, że w całej zbiorowości maturzystów 42,6\% ankietowanych jest zadowolonych z działalności Kościoła w rozwiązywaniu problemów jednostek, 51,2\% problemów rodziny, 36,5\% - problemów młodzieży, 30,6\% - problemów poszczególnych warstw społecznych, i 41,0\% - problemów narodu (wskaźniki niezadowolenia

21 M. Marody, S. Mandes, Przemiany polskiej religijności, [w:] Wartości i zmiany..., s. 198-199.

22 P. Gierech, Kilka uwag o polskiej mtodzieży początku XXI wieku, „Teologia Polityczna” 2009-2010, nr 5, s. 234.

23 T.Żukowski, Podsumowanie, [w:] Wartości Polaków a dziedzictwo Jana Pawta II, red. tenże, Warszawa 2009, s. 280. 
odpowiednio - 35,5\%, 32,2\%, 45,3\%, 45,1\%, 35,8\%; wskaźniki niezdecydowanych lub nieudzielających odpowiedzi - 21,9\%, 16,5\%, 18,2\%, 24,3\%, 23,3\%). Społeczna działalność Kościoła była częściej kwalifikowana pozytywnie niż negatywnie w odniesieniu do jednostek, problemów rodziny i narodu, a rzadziej w odniesieniu do problemów młodzieży i warstw społecznych. Przeciętny wskaźnik deklarowanego zadowolenia z działalności Kościoła w pięciu analizowanych sferach życia codziennego wynosił $40,4 \%$, wskaźnik niezadowolenia - 38,8\%, wskaźnik niezdecydowania lub braku odpowiedzi - 20,8\%. Pełna aprobata działalności Kościoła w kwestiach społecznych (odpowiedzi „tak”) była wyrażana przez zdecydowaną mniejszość badanych maturzystów (wskaźnik przeciętny - 10,6\%) ${ }^{24}$.

Przedstawione wybrane wyniki badań empirycznych nie są w pełni porównywalne, ale wydają się świadczyć o mniejszym krytycyzmie wobec Kościoła ludzi dorosłych niż młodzieży oraz o słabszym podkreślaniu roli i znaczenia Kościoła w życiu publicznym. Rola ta jest związana bardziej ze sferą problemów duchowych człowieka niż z dziedziną konkretnych kwestii życia codziennego, bardziej ze sferą indywidualną niż społeczną. W pluralizującym się społeczeństwie polskim Kościół nie może pretendować do roli autorytetu wszystkich obywateli, całego społeczeństwa. Pomimo relatywnie wysokiego zaufania społecznego do Kościoła jego kompetencje są lokalizowane bardziej w dziedzinie problemów i potrzeb duchowych ludzi. Negatywne przemiany dokonujące się w postawach wobec Kościoła w młodszym i starszym pokoleniu Polaków mogą iść zarówno w kierunku antykościelności (odrzucenie Kościoła), jak i w kierunku akościelności (obojętność wobec Kościoła), ale nie można wykluczyć pewnych form rewitalizacji zaufania kościelnego.

W świetle wyników sondaży opinii publicznej i badań socjologicznych od $46,0 \%$ do $65,2 \%$ badanych dorosłych Polaków akceptowało kompetencje Kościoła w sprawach moralnych, duchowych i społecznych. W odniesieniu do środowisk młodzieżowych wskaźnik ten spadał wyraźnie poniżej 50\%, a w niektórych środowiskach społecznych nawet poniżej 40\%. Ocena konkretnej działalności Kościoła katolickiego dokonana przez młodzież - ujmowana w kontekście osiąganych rezultatów - jest dość zróżnicowana. Można by nawet twierdzić, że zbliżamy się do sytuacji kryzysowej, bowiem znaczna część młodych Polaków wyraża niezadowolenie - mniej lub bardziej intensywne - z odpowiedzi, jakie Kościół daje na problemy społeczne jednostek, rodzin, młodzieży, warstw społecznych i narodu. W świetle zgromadzonych danych empirycznych można by mówić o tym, że początek emigracji młodych z Kościoła jest już przygotowany, a nawet już się rozpoczął. Wyrasta pokolenie z różnymi uprzedzeniami wobec niego, a także - być może - ze świadomością niejasnej roli Kościoła w społeczeństwie. Generalnie postawy badanej młodzieży można by określić jako mieszaninę pro i contra, przy czym elementy sprzeciwu są mocno artykułowane, niekiedy w formie dość radykalnej.

24 J. Mariański, Kościót katolicki w Polsce w przestrzeni życia publicznego. Studium socjologiczne, Toruń 2013, s. 179-180. 


\section{KRZYŻ I INNE SYMBOLE RELIGIJNE W PRZESTRZENI PUBLICZNEJ}

Aprobata lub dezaprobata obecności Kościoła katolickiego w życiu publicznym w Polsce znajduje swoje odniesienia do obecności krzyża i symboli religijnych. Kwestia obecności symboli religijnych w przestrzeni publicznej stała się w ostatnich kilku latach przedmiotem ostrej debaty na temat roli i wpływu Kościoła w naszym kraju, aż po domaganie się usunięcia krzyża z sali posiedzeń Sejmu RP. Jedni powołują się na świeckość państwa i domagają się, by sfera publiczna była wolna od symboliki religijnej i treści o charakterze światopoglądowym, jako że ich obecność w sferze publicznej narusza wolność sumienia i wyznania oraz prawa osób inaczej wierzących lub niewierzących. Drudzy wskazują na prawo do swobody wyrażania opinii i przekonań światopoglądowych także w życiu publicznym oraz manifestowania wartości ważnych dla wspólnoty katolickiej, będącej większością w społeczeństwie. Kwestię tę w sposób ogólny rozstrzyga Konstytucja RP: Wtadze publiczne w Rzeczypospolitej Polskiej zachowuja bezstronność w sprawach przekonań religijnych, światopogladowych i filozoficznych, zapewniając swobode ich wyrażania w życiu publicznym (art. 25, p. 2).

Od kilku lat podejmowane są przez niektóre partie polityczne próby usuwania krzyża z przestrzeni publicznej, zwłaszcza z sali sejmowej. Według nich w nowoczesnym państwie nie ma miejsca na symbole religijne w przestrzeni publicznej. Nie traktują oni krzyża jako symbolu narodowego, źródła polskiej tożsamości, znaku naszej walki o wolność i niepodległość, jako wyrażenia czci dla naszej tradycji i kultury. Spory polityczne o krzyż w sali sejmowej trwają i trwać będą. Przeciwnicy krzyża w sali sejmowej uznają jego obecność w instytucjach publicznych jako znak uzależnienia się władz państwowych od Kościoła, co ich zdaniem jest sprzeczne z Konstytucją, która mówi o bezstronności władzy w sprawach światopoglądowych i w kwestiach wiary lub narusza dobra osobiste ludzi niewierzących. Jeżeli nawet krzyż może być pewnym dyskomfortem dla ludzi niewierzących, to bynajmniej - twierdzą inni - nie narusza to swobody sumienia ateistów, nie oznacza przejawu dyskryminacji i nie jest niezgodne z zasadami Konstytucji, konkordatu czy konwencji europejskich. Obecność krzyża i w ogóle symboli religijnych w przestrzeni publicznej będzie trwałym przedmiotem dyskursu społecznego, a zwłaszcza politycznego.

Sondaże opinii publicznej dostarczają danych empirycznych wskazujących na zróżnicowany poziom aprobaty umieszczania symboli religijnych w przestrzeni publicznej. Obecność religii i Kościoła w sferze publicznej uzyskuje znaczną aprobatę ogółu Polaków. Z przeprowadzonego w 1997 roku przez Instytut Studiów Politycznych PAN sondażu wynika, że prawie 90\% dorosłych Polaków akceptowało krzyże w budynkach publicznych (urzędy, szkoły). Ponad 80\% aprobowało lekcje religii w szkołach i religijny charakter przysięgi żołnierskiej, 70\% - akceptowało obecność księży w telewizji publicznej i fakt, że Kościół wypowiada się na tematy moralne i społeczne. Tylko $40 \%$ wypowiadało się pozytywnie o tym, że Kościół zajmuje stanowisko wobec przyjmowanych przez Sejm RP ustaw. Zdaniem większości 
Polaków Kościół nie powinien zajmować się polityką ani mieszać się do procesów ustawodawczych ${ }^{25}$.

Według sondażu CBOS z 1997 roku 52\% badanych dorosłych Polaków wypowiadało się za obecnością krzyża w sali obrad sejmowych, $30 \%$ było temu przeciwnych, a $16 \%$ - to niezdecydowani ${ }^{26}$. W marcu 2011 roku - jak wynika to z sondażu CBOS - 57\% badanych dorosłych Polaków deklarowało pogląd, że polskie społeczeństwo jest chrześcijańskie, więc obywatele mają prawo do obecności krzyża w miejscach publicznych; 17\% - że chociaż większość Polaków jest chrześcijanami, należy przyjąć zdanie mniejszości i jeśli komuś przeszkadza krzyż, to należy go usunąć z miejsc publicznych; $24 \%$ - że kwestia obecności krzyża w miejscach publicznych jest dla respondenta obojętna; 3\% - trudno powiedzieć. Stanowisko aprobujące krzyż w przestrzeni publicznej częściej prezentowali respondenci praktykujący kilka razy w tygodniu (82\%), głęboko wierzący (78\%), o poglądach prawicowych (84\%), deklarujący silne związki z Janem Pawłem II (76\%), będący w wieku powyżej 64 lat $(71 \%)$, rolnicy $(79 \%)$, mieszkańcy wsi $(70 \%)$ i z wykształceniem podstawowym (68\%). Najrzadziej stanowisko to aprobowali niewierzący (11\%), niepraktykujący (14\%) i mieszkańcy największych miast (39\%) ${ }^{27}$.

Według sondażu CBOS z listopada 2011 roku 9,9\% badanych dorosłych Polaków deklarowało, że rażą ich krzyże w budynkach publicznych, np. w urzędach i szkołach, $88,5 \%$ - nie rażą, i 1,7\% - trudno powiedzieć. W całej zbiorowości 11,0\% respondentów twierdziło, że zdecydowanie lub raczej razi ich dodawanie przez prezydenta, premiera, ministrów czy posłów w przysiędze (ślubowaniu) słów: „Tak mi dopomóż Bóg”, 86,8\% - że ich nie razi, 2,1\% - trudno powiedzieć, i 0,1\% - odmowa odpowiedzi. Nieco mniej badanych optowało za tym, że w sali obrad Sejmu RP powinien wisieć krzyż (60,0\% - tak, 17,2\% - nie, 20,6\% - obojętne, 2,1\% - trudno powiedzieć, 0,1\% - odmowa odpowiedzi). Na pytanie, czy w sytuacji, gdy w Sejmie zasiadają posłowie różnych wyznań i religii, powinny być symbole religijne, badani dorośli Polacy udzielili następujących odpowiedzi: powinny znajdować się symbole różnych religii, tych, których wyznawcy zasiadają w Sejmie - 19,0\%; powinien znajdować się tylko krzyż - 33,5\%; w ogóle nie powinno być symboli religijnych - 35,9\%; trudno powiedzieć $11,5 \%$; odmowa odpowiedzi - 0,1\%.34,0\% badanych deklarowało, że wieszanie krzyża w miejscach publicznych można uznać za naruszanie wolności osób niewierzących, $55,5 \%$ - nie narusza, $10,4 \%$ - trudno powiedzieć, 0,1\% - odmowa odpowiedzi ${ }^{28}$.

W latach 2009-2011 - według sondaży CBOS - nie nastąpiły zmiany w stosunku Polaków do obecności krzyża w Sejmie i w innych budynkach publicznych. W grudniu

25 T. Szawiel, Kościót polski widziany z zewnątrz, „Przegląd Powszechny” 2000, nr 11 (numer specjalny), s. 87.

26 Sprawa obecności krzyża w Sejmie, Komunikat z badań CBOS, nr BS/141/1997, Warszawa 1997, s. $1-2$.

27 A. Dobrzyńska, P. Gierech, $W$ dwadzieścia latpóźniej. Polacy o Janie Pawle II i jego nauczaniu w roczniceppielgrzymki do wolnej Polski, Komunikat z badań CBOS, nr BS/65/2011, Warszawa 2011, s. 19-20.

28 Wyniki badania „Aktualne problemy i wydarzenia”, Komunikat z badań CBOS, nr 258 (do użytku wewnętrznego), Warszawa 2011, s. 21-22. 
2009 roku tylko 7\% badanych deklarowało, że te symbole religijne ich rażą, 91\% że nie rażą, i $2 \%$ - trudno powiedzieć (w 2011 roku odpowiednio - 10\%, 80\%, 2\%). W trzy lata później nastąpiła tylko nieznaczna zmiana opinii (różnica 3\%). Jeszcze mniejsze zmiany zaznaczyły się w kwestii obecności krzyża w Sejmie. W 1997 roku $24 \%$ badanych uznało zdecydowanie, że krzyż powinien wisieć w sali posiedzeń Sejmu, $28 \%$ - raczej powinien, $15 \%$ - raczej nie powinien, $14 \%$ - zdecydowanie nie powinien, 16\% - jest to obojętne, 3\% - trudno powiedzieć (w 2011 roku odpowiednio: 33\%, 27\%, 7\%, 10\%, 21\%, 2\%). W latach 1997-2011 zwiększył się wskaźnik poparcia dla obecności krzyża w Sejmie (obecnie 60\%). Nieco inny kierunek zmian należy odnotować w kwestii obecności krzyża w budynkach publicznych w kontekście praw ludzi niewierzących. W 2009 roku 28\% badanych dorosłych Polaków deklarowało, że - w ich opinii - wieszanie krzyża w miejscach publicznych można uznać za naruszenie wolności ludzi niewierzących, w 2011 roku było już takich $34 \%{ }^{29}$.

W wielkich miastach aprobata dla eksponowania symboli religijnych poza obiektami sakralnymi jest na niższym poziomie niż w mniejszych ośrodkach miejskich i w środowiskach wiejskich. Według badań socjologicznych w Warszawie zrealizowanych w 2010 roku przez Polski Pomiar Postaw i Wartości największą liczbę zwolenników obecności krzyża uzyskują instytucje lecznicze i opiekuńcze (szpitale - 59,5\%, domy opieki społecznej - 57,3\%), nieco mniej instytucje edukacyjne i wychowawcze (przedszkola - 51,8\%, szkoły i uczelnie - 52,5\%, domy wychowawcze - 52,7\%) i jeszcze mniej obiekty użyteczności publicznej (Sejm - 44,6\%, urzędy administracji publicznej 42,2\%). Osoby wierzące i praktykujące oraz starsi wiekiem znacznie częściej opowiadają się za obecnością krzyża w obiektach użyteczności publicznej niż młodzi mieszkańcy Warszawy, inteligencja oraz obojętni religijnie i niewierzący ${ }^{30}$.

Obecność w przestrzeni życia publicznego symboli religijnych stanowi ważny element dyskursu publicznego. Ich aprobata lub dezaprobata wiąże się z tożsamością polityczną Polaków, nie tylko samych polityków. Członkowie partii prawicowych deklarują się w ogromnej większości jako zwolennicy symboli religijnych w przestrzeni życia publicznego, członkowie partii lewicowych w znacznej części wypowiadają się przeciw tej obecności. Badania socjologiczne i sondaże opinii publicznej potwierdzają, że większość Polaków opowiada się za obecnością symboli religijnych w przestrzeni życia publicznego i uznaje, że ich obecność w budynkach publicznych nikomu nie powinna przeszkadzać. Ponad połowa badanych Polaków jest zdania, że krzyż powinien wisieć w sali obrad Sejmu RP. Wydaje się, że w ostatnich kilku latach aprobata obecności symboli religijnych w przestrzeni życia publicznego nieco słabnie, chociaż byłoby trudno określić rozmiary tego zjawiska.

Krzyż i inne symbole religijne w przestrzeni życia publicznego będą przedmiotem wielu dyskusji, zwłaszcza jeżeli będzie dokonywać się przyspieszony proces sekularyzacji

29 B. Roguska, Obecność krzyża w przestrzeni publicznej, Komunikat z badań CBOS, nr BS/153/2011, Warszawa 2011, s. 1-7.

30 S.H. Zaręba, Treści religijne w przestrzeni publicznej. Kompozycja czy dekompozycja?, [w:] Lokalna wspólnota wyobrażona. Warszawa i jej mieszkańcy 2010, red. S.H. Zaręba, Warszawa 2012, s. 135-137. 
społeczeństwa. Dyskursy tego rodzaju są częścią szerszego problemu dotyczącego miejsca religii w sferze publicznej, a zwłaszcza politycznej. Usuwanie symboli religijnych jest prostą konsekwencją prób oderwania porządku prawnego i politycznego od dawnego podłoża kulturowego i religijnego. Jeżeli nawet większość Polaków jest przeciwna udziałowi Kościoła w życiu politycznym, to także większość nie wyraża sprzeciwu wobec obecności krzyża i symboli religijnych w przestrzeni publicznej. Pewna część Polaków (od 20\% do 30\%) wyraża obojętność lub sprzeciw odnoszący się do umieszczania symboli religijnych w urzędach użyteczności publicznej. Trzeba jednak dodać, że decydującym czynnikiem będą decyzje polityczne organów sprawujących władzę w naszym państwie, a także różne siły antyewangelizacyjne w społeczeństwie polskim występujące przeciwko obecności symboli religijnych w przestrzeni publicznej.

\section{UWAGI KOŃCOWE}

Kościół w Polsce funkcjonuje jeszcze do pewnego stopnia jako instytucja i jako wspólnota o zobowiązaniach normatywnych. Jego kondycja jest o wiele bardziej korzystna niż w Europie Zachodniej, ale nie bezproblemowa. Należy wyrazić nadzieję, że katolicy polscy, nie rezygnując ze swojej głębokiej wiary, będą odnajdywać swoją drogę w zdrowo otwartym społeczeństwie, pluralistycznym i nacechowanym szacunkiem, potrafią iść drogą postępu i modernizacji społecznej. Odnowa kulturowa i odkrywanie na nowo fundamentalnych wartości moralnych i duchowych, na których można budować lepszą przyszłość, potrzebują religii i Kościoła. Niezależnie od tego, jak Kościół katolicki w Polsce będzie ewoluował w przyszłości, będzie on w dalszym ciągu wywierał wpływ na wiele aspektów życia jednostkowego i zbiorowego. Nie oznacza to „mieszania się” w bieżącą politykę. Coraz więcej przedstawicieli duchowieństwa rozumie, że zaangażowanie się Kościoła w spory polityczne może mu przynieść więcej szkód niż zysków. W tym kontekście znany socjolog warszawski Maria Libiszowska-Żółtkowska stawia nawet tezę, że na dłuższą metę większą szkodę może wyrządzić Kościołowi deprywatyzacja niż prywatyzacja religii ${ }^{31}$.

Większość Polaków jest przekonanych o wpływie Kościoła na różne sfery życia publicznego, zwłaszcza w dziedzinie politycznej. Pogląd ten dominuje wśród prawie dwóch trzecich dorosłych Polaków, ale także wśród młodzieży (jeszcze w nieco wyższym stopniu). Oznacza to, że Kościół jest postrzegany przez część polskiego społeczeństwa jako instytucja quasi-polityczna, a przynajmniej usiłująca pełnić funkcje polityczne. Ten pogląd - dość rozpowszechniony wśród Polaków - utrzymuje się od 1989 roku na względnie stabilnym poziomie. Wśród tych, którzy uważają, że Kościół zajmuje zbyt dużo miejsca w życiu publicznym naszego kraju, znajdują się ci, u których każde odniesienie do spraw publicznych wywołuje reakcję odrzucenia, jak i ci, którzy zajmują postawę umiarkowaną, uważając, że byłoby lepiej, gdyby Kościół mniej ingerował

31 M. Libiszowska-Żółtkowska, Socjologia religii w Polsce - historia i wspótczesność, [w:] Studia nad życiem spoteczno-kulturalnym Polaków w Niemczech, red. W. Misiak, J. Surzykiewicz, Toruń 2012, s. 18, Cztowiek, Środowisko Życia, Edukacja. 
w sprawy życia publicznego, a zwłaszcza politycznego. Większość Polaków akceptuje systemowe zasady rozdziału Kościoła i państwa, chociaż blisko połowa badanych nie ma nic przeciwko temu, by rządzący kierowali się zasadami społecznej nauki Kościoła. Poglądy wielu Polaków na miejsce i rolę Kościoła w życiu publicznym kraju są do pewnego stopnia ambiwalentne, a nawet niekonsekwentne i niespójne. Przedmiotem kontrowersji jest obecność symboli religijnych w przestrzeni życia publicznego, chociaż większość społeczeństwa wypowiada się o nich z aprobatą.

Procesy sekularyzacyjne $\mathrm{w}$ odniesieniu do wiary i wierzeń religijnych oraz więzi z Kościołem - jakkolwiek nie przebiegają w sposób skokowy - dokonują się bez wątpienia w społeczeństwie polskim, ale interpretacje tego zjawiska mogą być różne. Religia i Kościół katolicki w Polsce nie utrzymają w dotychczasowych kształtach swojej dominującej pozycji na współczesnym rynku światopoglądowym, a niektóre formy myślenia i działania będą się wyodrębniać ze sfery religijno-kościelnej. Można przypuszczać, że w XXI wieku będą zaznaczać się procesy „pełzającej” (spowolnionej) sekularyzacji, podobne (ale nie identyczne) do tych, jakie zaistniały już w wysoko rozwiniętych społeczeństwach pluralistycznych. Zostaną uruchomione innego typu czynniki energicznie wspierające i inicjujące procesy sekularyzacyjne niż te, które działały w okresie realnego socjalizmu (np. niewiara lub indyferentyzm religijny wywodzące się z przesłanek ideologii liberalnej, wpływy kulturowe globalizacji). Religijność Polaków jest zagrożona nie tylko przez zmiany społeczno-kulturowe, ale i przez różnego rodzaju ofensywy ideologiczne, wrogie chrześcijaństwu, a szczególnie Kościołowi katolickiemu. Procesy zmian obecności Kościoła katolickiego w przestrzeni życia publicznego nie dają się jednoznacznie określić.

Kościoły, w tym szczególnie Kościół katolicki w Polsce, muszą redukować swoje „uwikłanie” w sferę życia politycznego i koncentrować się na aktywnym udziale w rozwiązywaniu ważnych problemów społecznych, zwłaszcza tych o wymiarze etycznym. W społeczeństwie obywatelskim religia nie musi być traktowana jako intruz $\mathrm{w}$ sferze życia publicznego. Nowoczesne, funkcjonalnie zróżnicowane społeczeństwo wymaga uszanowania autonomii dziedziny życia pozareligijnego. Kościoły muszą utrzymywać odpowiedni dystans wobec życia politycznego i nie mogą ustawicznie reagować na przemijające wydarzenia życia społecznego. Być może będzie to oznaczać zmniejszenie zainteresowania się sprawami życia publicznego. Równocześnie Kościół - ze swej istoty - pozostaje przede wszystkim instytucją religijną, odnawiającą się ustawicznie poprzez swoje siły duchowe, jest święty i ciągle potrzebujący odnowy. Jego jutro zaczyna się już dzisiaj, w teraźniejszości. On sam jest potrzebny na różne sposoby społeczeństwu. Polskiej demokracji potrzebny jest Kościót, bowiem polska demokracja potrzebuje gtosu sumienia. Polskiej demokracji potrzebny jest Kościót, który mówi językiem Ewangelii, a nie językiem krucjaty; Kościót, który jest i pozostanie znakiem sprzeciwu, a nie znakiem przymusu. Kościót, który przywróci nam wiarę, że można zto dobrem zwyciężaći ${ }^{32}$. Potrzebny jest on w budowaniu przedpolitycznych, czyli moralnych, fundamentów ładu demokratycznego.

32 A. Michnik, Wściektość i wstyd, Warszawa 2005, s. 228. 
Procesy sekularyzacyjne w Polsce nie są jeszcze zbyt zaawansowane, a katolicyzm nie jest tak silny, jak mniemają jego obrońcy, ani tak słaby, jak opisują to jego krytycy. Jest on niewątpliwie wewnętrznie zróżnicowany i wielosektorowy. Katolicyzm polski jest jakby „wielogłosowy”, może nawet wydawać się swoistą fortecą. Z zewnątrz instytucjonalny gmach Kościoła jest jakby nietknięty (np. autodeklaracje wyznaniowe i religijne, uczestnictwo w praktykach religijnych), jeżeli przyjrzeć się jednak dokładniej, to można dostrzec poważne rysy sięgające aż do fundamentów jego struktury, zwłaszcza w dziedzinie moralności. Katolicka Polska dopiero po dwóch dekadach transformacji ustrojowej i społeczno-kulturowej, po wejściu do Unii Europejskiej, zaczyna w sposób bardziej wyraźny zmagać się z wyzwaniami postchrześcijańskiej czy postsekularnej Europy. Kościół katolicki w naszym kraju staje częściowo na rozstajnych drogach, zarówno gdy chodzi o jego miejsce w przestrzeni życia publicznego, jak i o postawy oraz zachowania religijne jego członków.

\section{BIBLIOGRAFIA}

Boguszewski R., Religia i religijność Polaków w zmieniajacym się spoteczeństwie, [w:] Życie po zmianie. Warunki zycia i satysfakcje Polaków, red. K. Zagórski, Warszawa 2009.

Boguszewski R., Zmiany w zakresie wiary i religijności Polaków po śmierci Jana Pawta II, Komunikat z badań CBOS, nr BS/49/2012, Warszawa 2012.

Borowik I., Religijność w Polsce okresu transformacji - na tropach zmian, [w:] Polska poczattu XXI wieku. Przemiany kulturowe i cywilizacyjne, red. K. Frysztacki, P. Sztompka, Warszawa 2012.

Dobrzyńska A., Gierech P., $W$ dwadzieścia lat później. Polacy o Janie Pawle II i jego nauczaniu w rocznice pielgrzymki do wolnej Polski, Komunikat z badań CBOS, nr BS/65/2011, Warszawa 2011.

Drozdowski R., Demokratyczne spoteczeństwo obywatelskie w Polsce w obecnych warunkach funkcjonowania państwa, [w:] Religia i Kościót w spoteczeństwie demokratycznym i obywatelskim w Polsce. Między losem a wyborem, red. J. Baniak, Poznań 2012.

Feliksiak M., Oceny instytucji publicznych, Komunikat z badań CBOS, nr BS/141/2014, Warszawa 2014.

Gierech P., Kilka uwag o polskiej mtodzieży początku XXI wieku, „Teologia Polityczna” 2009-2010, nr 5 .

Grabowska M., Religijność i Kościót w procesie transformacji w Polsce, [w:] Pierwsza dekada niepodlegtości. Próba socjologicznej syntezy, red. E. Wnuk-Lipiński, M. Ziółkowski, Warszawa 2001.

Hipsz N., Polaków obraz rzeczywistościparafialnej, Komunikat z badań CBOS, nr BS/144/2011, Warszawa 2011.

Inglehart R. (ed.), Changing Human Beliefs and Values, 1981-2007. A Cross-Cultural Sourcebook based on the World Values Surveys and European Values Studies, Chichester 2010.

Jarosz M., Jaka Polska? [Wstęp], [w:] Polacy we wspólnej Europie. Dysproporcje materialne i spoteczne, red. M. Jarosz, Warszawa 2011. 
Kerševan M., Europejczycy jutra. Chrześcijanie bez Kościota - ludzie bez wiary, „Przegląd Powszechny" 2000, nr 11 (numer specjalny).

Kwestionariusz wywiadu EVS 2008, [w:] Wartości i zmiany. Przemiany postaw Polaków w jednoczącej się Europie, red. A. Jasińska-Kania, Warszawa 2012.

Libiszowska-Żółtkowska M., Socjologia religii w Polsce - historia i wspótczesność, [w:] Studia nad zyciem spoteczno-kulturalnym Polaków w Niemczech, red. W. Misiak, J. Surzykiewicz, Toruń 2012, Cztowiek, Środowisko Życia, Edukacja.

Mariański M., Kościót katolicki w Polsce w przestrzeni życia publicznego. Studium socjologiczne, Toruń 2013.

Marody M., Mandes S., Przemiany polskiej religijności, [w:] Wartości i zmiany. Przemiany postaw Polaków w jednoczącej się Europie, red. A. Jasińska-Kania, Warszawa 2012.

Michnik A., W'sciektość i wstyd, Warszawa 2005.

Ochocki A., Kościót katolicki a sprawy publiczne w Polsce, [w:] Kościót katolicki na początku trzeciego tysiąclecia w opinii Polaków, red. W. Zdaniewicz, S.H. Zaręba, Warszawa 2004, Studia Socjologiczno-Religijne, nr 23.

Opinie Polaków o Kościele 2010, Komunikat z badań TNS OBOP (grudzień 2010), Warszawa 2010.

Pollack D., Religion und Politik in den postkommunistischen Staaten Ostmittel- und Osteuropas, „Aus Politik und Zeitgeschichte” 2002, Vol. B 42-43, s. 18-22.

Pollack D., Das Verhältnis von Religion und Politik in den postkommunistischen Staaten Ostmittel-und Osteuropas und seine Auswirkungen auf die Vitalität des religiösen Feldes, [w:] Politik und Religion, Hrsg. M. Minkenberg, U. Willems, Wiesbaden 2003, Politische Vierteljahresschrift. Sonderheft, 33.

Postawy Polaków wobec Kościota i Konkordatu w lutym i marcu 1997 roku, Komunikat z badań OBOP (marzec 1997), Warszawa 1997.

Roguska B., Opinie o dziatalności Kościota, Komunikat z badań CBOS, nr BS/37/2007, Warszawa 2007.

Roguska B., Obecność krzyża w przestrzeni publicznej, Komunikat z badań CBOS, nr BS/ 153/2011, Warszawa 2011.

Sprawa obecności krzyża w Sejmie, Komunikat z badań CBOS, nr BS/141/1997, Warszawa 1997.

Szafraniec K., Mtodzi 2011, Warszawa 2011.

Szawiel T., Kościót polski widziany z zewnątrz, „Przegląd Powszechny” 2000, nr 11 (numer specjalny).

Wyniki badania „Aktualne problemy i wydarzenia”, Komunikat z badań CBOS, nr 258 (do użytku wewnętrznego), Warszawa 2011.

Wyniki badania „Aktualne problemy i wydarzenia”, Komunikat z badań CBOS, nr 293 (do użytku wewnętrznego), Warszawa 2014.

Zaręba S.H., Treści religijne w przestrzeni publicznej. Kompozycja czy dekompozycja?, [w:] Lokalna wspólnota wyobrażona. Warszawa i jej mieszkańcy 2010, red. S.H. Zaręba, Warszawa 2012.

Żukowski T., Podsumowanie, [w:] Wartości Polaków a dziedzictwo Jana Pawta II, red. tenże, Warszawa 2009. 
Prof. dr hab. Janusz MARIAŃSKI - socjolog zajmujący się problematyką socjologii moralności i socjologii religii, wieloletni profesor Katolickiego Uniwersytetu Lubelskiego Jana Pawła II i kierownik Katedry Socjologii Moralności, profesor zwyczajny w Wyższej Szkole Nauk Społecznych w Lublinie. Opublikował m.in. monografie z socjologii moralności i socjologii religii: Kościót katolicki w Polsce w przestrzeni życia publicznego. Studium socjologiczne (Torun 2013); Kościót katolicki w spoteczeństwie obywatelskim. Refleksje socjologiczne (Lublin 1998); Kościót w spoteczeństwie przemystowym (Warszawa 1983); Kryzys moralny czy transformacja wartości? Studium socjologiczne (Lublin 2001); Matżeństwo i rodzina w świadomości mtodzieży maturalnej - stabilność i zmiana (Toruń 2012); Praktyki religijne w Polsce w procesie przemian. Studium socjologiczne (Sandomierz 2014). 